\title{
Os usos da Justiça na busca por direitos: estratégias de reivindicação operária na cidade-fábrica Rio Tinto (Paraíba, 1959-1964)
}

\section{Eltern Campina Vale*}

Resumo: Este artigo busca analisar as ações trabalhistas movidas pelos operários da cidade-fábrica de Rio Tinto (PB). Os processos tramitaram na Junta de Conciliação e Julgamento de João Pessoa e no Fórum de Rio Tinto, constituindo um novo espaço de reivindicação e resistência dos operários nas décadas de 1950 e 1960. Estes, por sua vez, eram conhecedores de que a Legislação Trabalhista amparava suas reivindicações e que, deste modo, seria uma outra via para a luta por seus direitos. Os processos analisados demonstram as formas como empregadores e empregados, diante da Consolidação das Leis do Trabalho - CLT, travaram a luta jurídica de redefinição de relações, no período entre 1959 e 1964, quando as ações se avolumaram.

Palavras-Chave: Direitos do trabalho; Trabalhadores; Cidade-Fábrica de Rio Tinto

Abstract: This article aims to analyze the worker's labor claims in the Rio Tinto town-factory (PB). The lawsuits were filed in the Conciliation and Trial Court of João Pessoa and in the Rio Tinto Forum, and promptly became a new space of laborers demand and resistance in the 1950s and 1960s. Workers knew that the labor laws supported their claims and, thus, that this could be another way of fighting for their rights. The analyzed lawsuits show how employers and employees fought legally to redefine their relationship in face of the Consolidation of Labour Laws, between the years of 1959 and 1964, when the lawsuits became more frequent. Keywords: Labor rights; Workers; Rio Tinto Town-Factory.

Em 1960, a operária Maria do Carmo Silva é tecelã na fábrica de tecidos Rio Tinto, na Paraíba ${ }^{1}$. No entanto, problemas de saúde, diagnosticados pela perícia médica do Instituto de Assistência Previdenciária dos Industriários - IAPI, terminam por afastá-la do trabalho.

\footnotetext{
* Professor Auxiliar do Departamento de Geo-História da Universidade Estadual da Paraíba. Mestre em História Social pela Universidade Federal do Ceará .

${ }^{1}$ Localizada a 52 km da capital da Paraíba, João Pessoa, a cidade-fábrica de Rio Tinto foi edificada entre os anos de 1917 e 1924, ano de sua inauguração. Seu acesso se dá através das rodovias BR-101 (João Pessoa-Natal) e PB-041, fazendo fronteira com os municípios de Mamanguape, Baía da Traição e Mataraca. De propriedade da família Lundgren, a tecelagem se constituía em filial de outro empreendimento similar, localizado em Paulista, próximo a Recife. Juntas, desfrutaram de amplo destaque entre as fábricas têxteis do Brasil, destacando-se como umas das que mais obtiveram retorno financeiro. Rio Tinto chegou a contar com cerca de 13.000 trabalhadores, e destacou-se no cenário social paraibano como um dos mais emblemáticos e atuantes movimentos de trabalhadores. A fábrica, que teve seu auge produtivo nas décadas de 1940 a 1960, encerrou suas atividades em 1990.
} 
Como procedimento comum é atestada a sua inaptidão, sendo-lhe concedida aposentadoria provisória.

Passados três anos a se recuperar, a tecelã em maio de 1963 se dirige à sede do IAPI, em Rio Tinto, para nova perícia médica que comprova seu restabelecimento físico. De posse de laudo do instituto, a tecelã se apresenta à fábrica para reassumir suas funções. Ao procurar a direção para o retorno ao trabalho, devido à recuperação de seu estado de saúde, recebe um comunicado ríspido, de que a fábrica não mais precisava dos seus serviços. 0 diretor complementa, informando que seu contrato de trabalho havia sido rescindido e que receberia uma indenização pelos anos trabalhados ${ }^{2}$.

Sem titubear, Maria do Carmo se recusa a receber a indenização. Sai da fábrica e acorre ao Sindicato Têxtil, procurando o advogado José Gomes da Silva ${ }^{3}$ com o propósito de acionar judicialmente a tecelagem, visando à readmissão ao trabalho. Ao decidir pela ação, demonstra estar ciente de que as leis trabalhistas a amparam, visto que é empregada com mais de dez anos de serviço, sendo estável. E pelo regulamento, a fábrica estava impedida de rescindir tal contrato de trabalho. A luta de Maria do Carmo é para fazer a lei ser cumprida, um embate para permanecer em seu posto de trabalho.

A história deste processo de Maria do Carmo, contra a medida ilegal da tecelagem, evidencia uma articulada ação dos trabalhadores na busca por direitos, tendo como suporte jurídico a Consolidação das Leis do Trabalho - CLT. Deste modo, a procura da Justiça pelos trabalhadores se dá inicialmente na Comarca de Mamanguape ${ }^{4}$ (nas décadas de 1930 a 1950), em seguida nas Juntas de Conciliação e Julgamento em João Pessoa (a partir de 1950) e, em outro momento, no Fórum de Rio Tinto, quando a Comarca é criada em 1959. Estes

\footnotetext{
${ }^{2}$ Processo n. 427/63. Junta de Conciliação e Julgamento de João Pessoa. Reclamante: Sindicato dos Trabalhadores na Indústria de Fiação de Mamanguape. Em favor de Maria do Carmo Silva. Reclamado: Companhia de Tecidos Rio Tinto. Objeto: Reintegração. Valor: Indeterminado. Procedência: Rio Tinto. 3 de junho de 1963. Arquivo das Varas do Trabalho de João Pessoa, PB. P. 6.

${ }^{3}$ Advogado à época da Federação dos Trabalhadores na Indústria da Paraíba, José Gomes da Silva se notabilizou por ser destacado militante comunista e atuar na defesa - na esfera jurídica - tanto dos trabalhadores de Rio Tinto como dos trabalhadores rurais - via Ligas Camponesas.

${ }^{4}$ Rio Tinto contou desde a sua inauguração com uma estrutura que a fazia autônoma tanto da vizinha Mamanguape como até mesmo da capital. Contava com escolas, cinema, padarias, farmácias, restaurantes, hotel, feira, clubes recreativos, hospital, campo de aviação, ferrovia, pequeno porto, e até mesmo o policiamento era feito pelos vigias da fábrica. Permaneceu enquanto distrito de Mamanguape até 1956, quando se emancipou.
} 
são usados enquanto possíveis espaços de luta, mediante ações coletivas e individuais. Esta ocorrência é ponto de similitude entre trabalhadores da cidade-fábrica de Paulista:

No período do final dos anos 40 e de toda a década de 50 , o recurso dos operários à lei e à justiça para a reivindicação dos seus direitos torna-se um fenômeno descentralizado e coletivo, desfechando-se massivamente sobre uma justiça trabalhista burocraticamente estruturada, e de capacidade de resolução lenta ${ }^{5}$.

A tramitação dos processos nas Juntas de Conciliação na capital, e não mais em Mamanguape a partir de 1950, pode ser entendida como uma estratégia dos mandatários da fábrica, os Lundgren. O fato acontece do mesmo modo em Paulista, e sobre a tática o jornal do PCB Folha do Povo, em edição de 17 de abril de 1952, registra:

[...] Os operários teriam que gastar dinheiro com a viagem e inclusive com hospedaria, no caso do julgamento da questão ser adiado como só acontece na Justiça do Trabalho. Há ainda outro fato a considerar: os trabalhadores, caso suas questões sejam transferidas para o Recife, deixariam de apresentar reclamações sobre suspensões injustas, falta de indenização, negativa do empregador em pagar as férias ou o repouso remunerado, etc. Isto aconteceu em Rio Tinto, quando os Lundgren conseguiram transferir o julgamento das questões da alçada da justiça comum da cidade para as juntas de conciliação e julgamento de João Pessoa. Devido à distância, os operários deixaram de fazer reclamações ${ }^{6}$.

Nos dois primeiros anos da década de 1950, a movimentação dos operários de Rio Tinto na Junta de Conciliação e Julgamento é evidente. No jornal $A$ União (publicação do Governo Estadual) há o registro, semanal e/ou quinzenal, dos resultados das audiências, quando os processos são julgados procedentes, em favor dos operários; outros, arquivados ou homologados por desistência. E essa desistência confirma em parte a denúncia do jornal Folha do Povo.

Tais processos seriam fontes primordiais para o estudo da Justiça do Trabalho na Paraíba, no entanto, no Arquivo das Varas do Trabalho, em João Pessoa, foram preservados poucos processos: foram incinerados, pois não tinha como acondicioná-los - assim afirma o funcionário, frustrando intentos de pesquisa. A propósito da preservação de arquivos basilares na escrita da história dos trabalhadores no Brasil, mormente de arquivos trabalhistas e judiciários, o pretexto do funcionário de que a Justiça do Trabalho não tem condições de conservar por um longo período esta documentação é objeto da reflexão de experiência similar de Sidney Chalhoub:

\footnotetext{
${ }^{5}$ LEITE LOPES, José Sérgio. A tecelagem dos conflitos de classe na cidade das chaminés. São Paulo: Marco Zero, 1988, p. 359.

${ }^{6}$ LEITE LOPES, José Sérgio. Op. cit., p. 364-365.
} 
Hoje, tempo de precarização, de perda de direitos dos trabalhadores, ouço a cada dia notícias e rumores sobre a destruição de autos da Justiça do Trabalho país afora. O foro está abarrotado, segundo a cantilena. Isto numa época em que há recursos tecnológicos de sobra para compactar e preservar o patrimônio documental da nação ${ }^{7}$.

Assim sendo, no arquivo das Juntas do Trabalho são conservadas apenas sete ações, movidas por trabalhadores de diferentes categorias e das seguintes indústrias: Companhia de Tecidos Paraibana, em Santa Rita; Fiação Brasileira de Sisal, em Bayeux; da Indústria da pesca e da extração do óleo da baleia, em Santa Rita; do Porto de Cabedelo; da Indústria de cimento, cal e gesso, de João Pessoa (Cia. de Cimento Portlland S/A); Teane Moinho do Brasil e Reunidas F. Matarazzo, ambas do setor de alimentação, na capital. São ações de: aviso prévio, décimo terceiro salário, diferença salarial, férias, dias de folga e indenização. Destes, somente um processo é oriundo de Rio Tinto: o que diz respeito à ação de reintegração movido pela tecelã Maria do Carmo Silva.

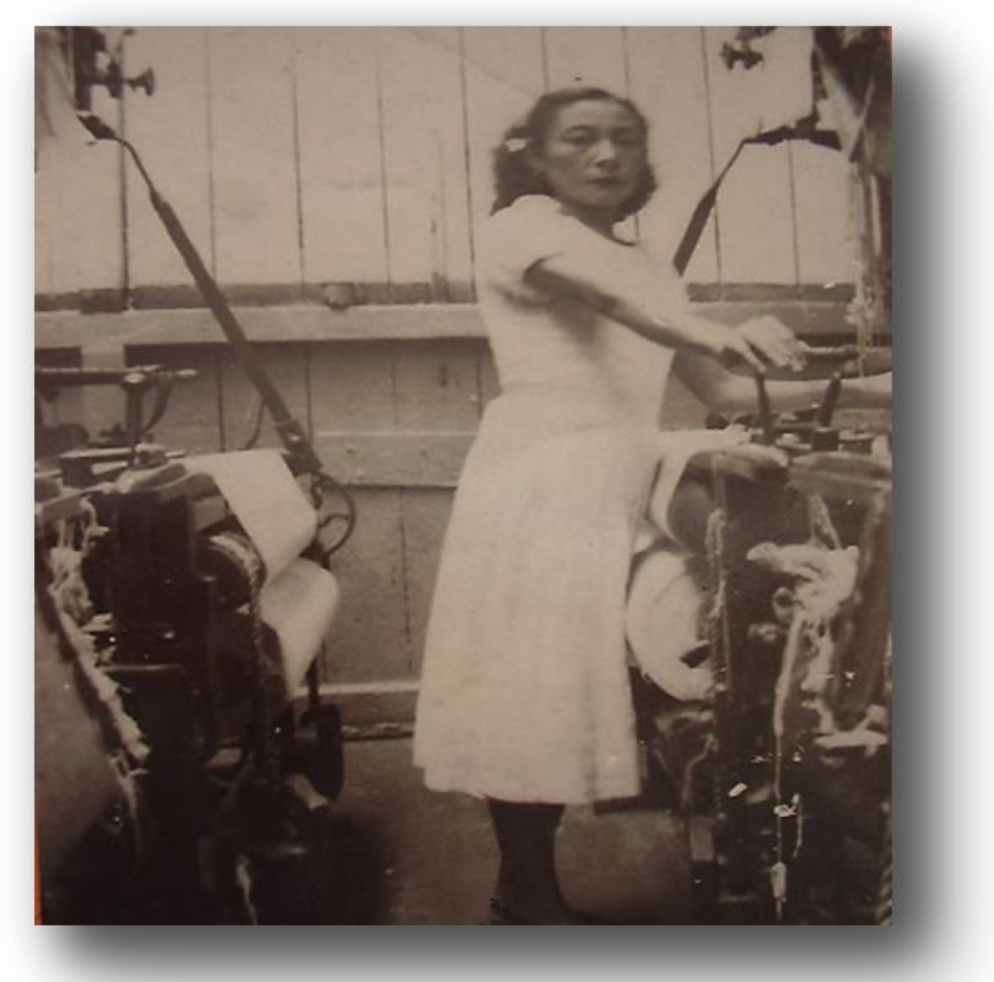

Figura 1 - Uma operária em atividade na tecelagem. Arquivo: Antônio Luiz da Silva (Rio Tinto - PB).

Contratada pela fábrica, em 1944, Maria do Carmo trabalha por produção na seção de tecelagem. Os problemas de saúde requerem afastamento do trabalho em três períodos:

\footnotetext{
${ }^{7}$ CHALHOUB, Sidney. Os arquivos dos trabalhadores. Revista de História da Biblioteca Nacional. Ano 2, n. 15. Rio de Janeiro, dezembro de 2006, p. 98.
} 
1948, 1950 e 1960. Na primeira audiência, de 4 de julho de 1963, na Junta de Conciliação, é apresentada a Carteira Profissional, onde se comprovam os afastamentos.

Em depoimento, após a argumentação apresentada pelo advogado da fábrica, a tecelã questiona sua rescisão, e em sua avaliação se considera uma boa operária, porquanto "prestou serviços nos anos indicados sem jamais ter dado lugar a repreensões e penalidade qualquer" $^{\prime \prime}$. Como trabalhadora, informa haver recebido prêmios em dinheiro pela produção. Importante destacar, a partir dessa informação, que alguns operários vivem esta situação, trabalhando mais de dez horas em turnos diários, em busca de gratificações adicionais de produção.

A demissão de Maria do Carmo está inserida no contexto de luta pela permanência no emprego. É cada vez mais comum a rescisão de contratos antes que se completem dez anos de trabalho.

Ainda na primeira audiência o advogado da tecelã ressalta sua estabilidade: " $n a$ forma da legislação especial somente podendo haver a reclamante cometido falta grave, após inquérito administrativo", destacando suas qualidades de boa trabalhadora e o amparo da lei trabalhista:

\begin{abstract}
A operária pertence a uma coletividade trabalhadora que gozava das prerrogativas sociais no momento, estipuladas nos decretos dos organismos salariais e outras vantagens conquistadas através das lutas dos trabalhadores, através das decisões normativas instituídas na Justiça do Trabalho, que considerando haver sido uma ótima empregada, sempre gozando dos melhores conceitos da empresa, recebendo trimestralmente prêmios por seus serviços e de acordo com o art.495 da CLT, deve-se ser reintegrada ${ }^{9}$.
\end{abstract}

A fala do defensor da Companhia de Tecidos Rio Tinto ${ }^{10}$, Giácomo Porto, contradita o amparo legal da tecelã e reafirma a rescisão de contrato de trabalho e indenização. Quanto à estratégia jurídica, Porto, durante seu argumento, tem apoio na interpretação do jurista Arnaldo Sussekind, para os arts. 475 a 478 da CLT, onde se assegura que o patrão pode demitir o operário com menos de dez anos de trabalho.

\footnotetext{
${ }^{8}$ Processo n. 427/63. Junta de Conciliação e Julgamento de João Pessoa. Reclamante: Sindicato dos Trabalhadores na Indústria de Fiação de Mamanguape. Em favor de Maria do Carmo Silva. Reclamado: Companhia de Tecidos Rio Tinto. Objeto: Reintegração. Valor: Indeterminado. Procedência: Rio Tinto. 3 de junho de 1963. Arquivo das Varas do Trabalho de João Pessoa, PB. P. 6.

${ }^{9}$ Processo n. 427/63. P. 6-7.

${ }^{10}$ A partir de 1950, a fábrica de tecidos Rio Tinto torna-se autônoma da de Paulista. E a denominação Companhia de Tecidos Paulista - Fábrica Rio Tinto seria substituída por Companhia de Tecidos Rio Tinto. Muitos trabalhadores deste período se reportam atualmente à fábrica como Companhia.
} 
Apresentadas as alegações, o juiz-presidente da Junta renova a proposta de conciliação, rejeitado pela tecelã. Segue a contenda jurídica e, em nova audiência, o advogado da tecelã reitera que de acordo com a lei, a fábrica só pode dispensar um trabalhador se antes houver aviso prévio, o que não ocorreu neste caso, desmontando o argumento do procurador da tecelagem. Em seguida, o juiz apresenta a decisão: a Junta delibera por maioria o pagamento em dobro da indenização.

A Companhia de Tecidos contesta a deliberação no Egrégio do Tribunal Regional do Trabalho, em Recife, requerendo reforma da sentença, para pagamento de uma indenização simples, e não em dobro. O representante da tecelã diverge da decisão e reitera, em contestação dirigida ao Egrégio, que este não deve acolher o recurso da Companhia por não encontrar apoio em nenhuma norma de direito ${ }^{11}$.

Contudo, em 4 de junho de 1964, os desembargadores do Tribunal Regional do Trabalho - 6a Região em Recife julgam por unanimidade pela reintegração de Maria do Carmo, seguida de pagamento de salários vencidos e vincendos. Em última cartada jurídica, a Companhia interpõe recurso de revista no Tribunal Superior do Trabalho. É o revés a favor da tecelã: em decisão final, de 17 de dezembro de 1964, os juízes do TST votam pela reintegração, e a Companhia é derrotada. Em agosto de 1965, a Justiça do Trabalho manda citá-la para cumprimento do determinado. No entanto, a tecelã decide pela conciliação, destacando as seguintes condições:

1a. A Companhia de Tecidos Rio Tinto paga à operária a importância de CR\$ 1.000.000 (um milhão de cruzeiros) referente a salários vencidos e vincendos e demais obrigações trabalhistas;

2a. Rescisão do contrato de trabalho com aviso prévio, férias, 13을;

3a. Renúncia expressa do seu direito de estabilidade ${ }^{12}$.

Em face desta desistência, devem ser levadas em conta: as dificuldades da tecelã em permanecer durante o processo de 1963 a 1965 sem receber salários; a relativa delonga da ação, já que a fábrica vai até as últimas instâncias jurídicas. Nesse ínterim, muitas das idas e vindas da tecelã à Junta na capital são amparadas financeiramente pelo sindicato têxtil. 0 acordo firmado é registrado no livro do sindicato, que assim observa:

A operária Maria do Carmo Silva, solteira, C.P. no. 20.052, Série 51으, residente e domiciliada na Rua Rio Branco, n. 6.461 em Rio Tinto, entrou em litígio com a Cia.

\footnotetext{
${ }^{11}$ Processo n. 427/63. P. 32.

12 Processo n. 427/63. P. 65.
} 
de Tecidos Rio Tinto, cuja questão foi resolvida a seu favor, ganhando unanimemente até no Supremo Tribunal. Mesmo assim a referida resolveu fazer um acordo na Junta de Conciliação e Julgamento de João Pessoa no valor de CR\$ 1.000.000 (um milhão de cruzeiros), em 3 de setembro de $1965^{13}$.

Ações trabalhistas como a desta tecelã vêm na esteira de outras tantas. E os uso sistemático da Justiça do Trabalho e do direito sugere uma pauta das reivindicações formuladas pelos trabalhadores em seus embates nas disputas judiciais.

Notadamente a partir do final da primeira metade de 1960 (exatamente no contexto em que a tecelã Maria do Carmo entra em embate jurídico com seus patrões), a tecelagem Rio Tinto passou por um processo contínuo de modernização do seu maquinário, que já se encontrava ultrapassado, se comparado com o das fábricas do Sudeste do Brasil. É nesta circunstância que a direção da fábrica utiliza estrategicamente o pretexto da contenção de despesas para promover o processo de demissão de centenas de operários, transformando o ambiente fabril e, por conseguinte, agregando novos temas à agenda de reivindicação e luta operária. Em nome da competitividade e do tempo de trabalho, a fábrica acrescenta novos equipamentos, e as máquinas modernas vão funcionando ao lado das antigas. As demissões são veiculadas em jornais da época, aparecem nos relatos de memória de trabalhadores e nos processos analisados. Em relação ao contingente operário em Rio Tinto, vejam-se os dados acerca das demissões:

Com relação à dispensa de operários, tem-se informação de que, em 1964, a Companhia de Tecidos Rio Tinto ocupava uma força de trabalho de aproximadamente 3.200 (três mil e duzentos) empregados em todos os setores. De janeiro de 1966 a outubro de 1967, foram despedidos 1.157 (mil cento e cinquenta e sete) operários. De 10 de janeiro a 15 de abril de 1968, foram indenizados 448 (quatrocentos e quarenta e oito) empregados. De 10 de janeiro de 1969 a 30 de abril de 1969, foram despedidos 284 (duzentos e oitenta e quatro) operários ${ }^{14}$.

\footnotetext{
${ }^{13}$ Livro de Registro das Questões na Junta de Conciliação e Julgamento. Arquivo do Sindicato Têxtil de Rio Tinto. Questão n.2. P. 6.

${ }^{14}$ MACÊDO, Maria Bernadete de. Inovações Tecnológicas e Vivência Operária - O caso de Rio Tinto 1950-1970. João Pessoa: Departamento de Economia da UFPB, 1986 (Dissertação), Vol.II. Op. cit., p.116-117. A modernização das tecelagens do Nordeste era parte da política de financiamento para o setor, idealizada pela Superintendência de Desenvolvimento do Nordeste - SUDENE e pelo Grupo de Trabalho para o Desenvolvimento do Nordeste - GTDN. Estavam inseridas na política do nacional-desenvolvimentismo, em que o incremento do desenvolvimento regional achava-se na ordem do dia.
} 


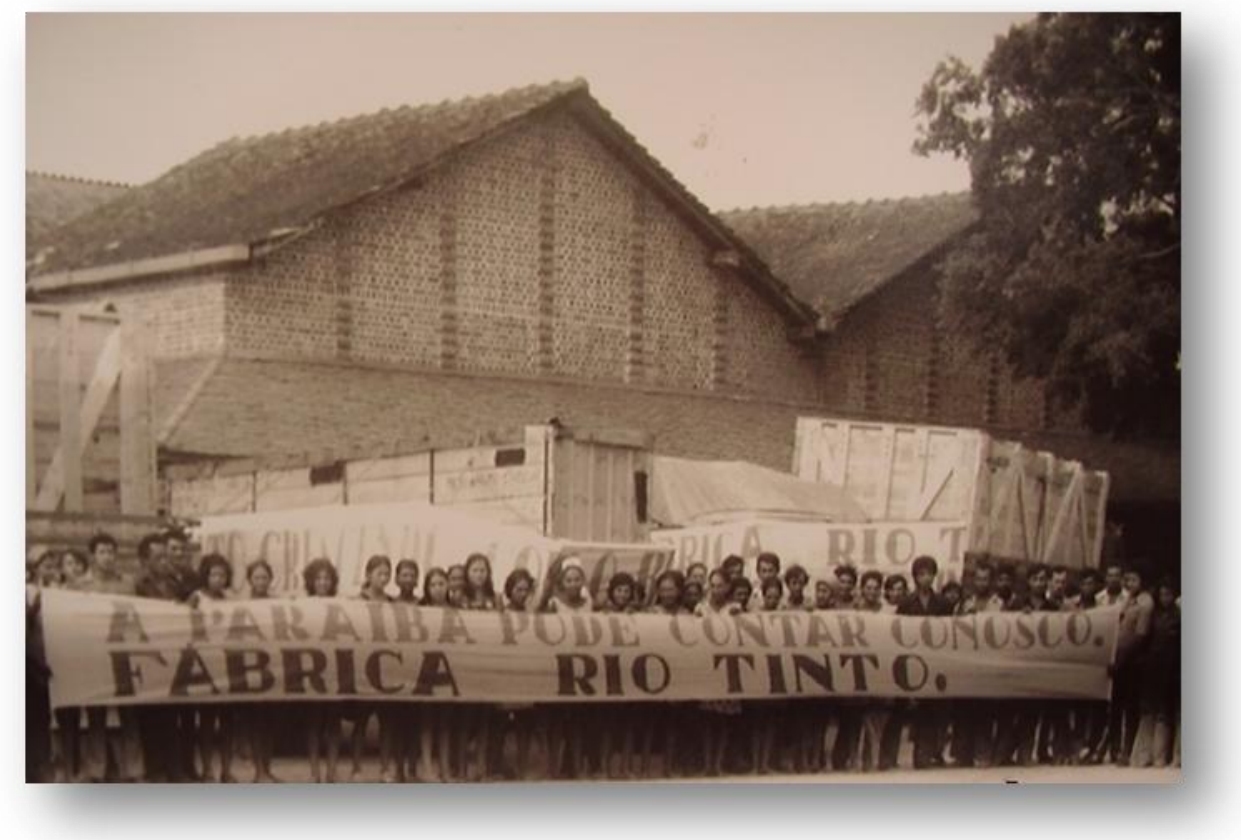

Figura 2 - Tomada de uma das frentes da fábrica de tecidos Rio Tinto. Chegada de novas máquinas à tecelagem. Primeira metade da década de 1960. Arquivo: Antônio Luiz da Silva (Rio Tinto - PB).

Os Lundgren, nesse interregno, procuram inserir nova estratégia de diminuição do número de trabalhadores. A fábrica põe em prática medidas, desde a rescisão de contratos de trabalho até a ação de despejo, na vila operária, dos trabalhadores demitidos. As ações movidas contra os patrões dão nova feição às reivindicações operárias. Porém, os trabalhadores ao fazerem uso deste espaço, enfrentariam a morosidade nos julgamentos, com processos que se arrastavam por anos a fio. Importa ressaltar que entre 1959 e 1964, a ocorrência bem como a quantidade de processos movidas contra a fábrica são expressivas. É o que em contexto nacional observa Ângela de Castro Gomes:

Grosso modo, portanto, de 1951 a 1964 ocorreu um significativo crescimento da força do movimento sindical, que se utilizou dos dois instrumentos principais que possuía para lutar pela aplicação e ampliação dos direitos do trabalho: as greves e o recurso à Justiça do trabalho ${ }^{15}$.

Os trabalhadores recorriam à Justiça para denunciar os Lundgren e não terem seus direitos usurpados. Assim, processos auxiliam no desvelamento da prática sistemática da tecelagem: dispensa de operários em torno dos dez anos de trabalho, para que não

\footnotetext{
${ }^{15}$ GOMES, Ângela Maria de Castro. Cidadania e direitos do trabalho. Rio de Janeiro: Jorge Zahar Ed. 2000, p. 48 (Descobrindo o Brasil). Outro estudo referente à Justiça do Trabalho e que tem interpretação diferente desta autora é: FRENCH, John D. Afogados em Leis: A CLT e a cultura política dos trabalhadores brasileiros. Tradução: Paulo Fontes. São Paulo: Ed. Fundação Perseu Ábramo, 2001, p. 19 (Coleção História do Povo Brasileiro).
} 
atingissem a estabilidade. As rescisões são acompanhadas de ações de despejo, pois os Lundgren alegam que uma vez rescindidos os contratos e sem vínculo com a fábrica, aqueles não poderiam permanecer na vila operária.

Sobressaem as histórias de Tertuliano Dias de Lima, Maria Francisca Santos, Nilson Francisco de Lira, Raimunda Soares da Silva, Floriano Rodrigues de Araújo, Maria Joselita G. de Barros, Izaura Vieira Guimarães, Diraniza Alves Pessoa, José Gomes Marçal e Luíza de Freitas Araújo. Em alguns, observam-se retaliações aos trabalhadores que participam de atividades político-sindicais de oposição aos Lundgren. Assim, os trabalhadores Durval Francisco de Assis, Francisco Vieira e Tertuliano Dias de Lima são demitidos devido à atuação político-partidária contrária aos interesses da fábrica, tanto em eleições sindicais como municipais.

O exemplo de Tertuliano Dias de Lima é elucidativo. Desde 1943 é operário da tecelagem, com estabilidade no emprego, e em abril de 1959 é demitido das Lojas Paulista, sem causa formal apresentada pela fábrica. Demitido, o trabalhador aciona os patrões na Junta de Conciliação, que, em julgamento por unanimidade, determina sua imediata readmissão.

Todavia, os Lundgren descumprem a determinação recorrendo a outras instâncias, como o 60 Tribunal Regional do Trabalho em Recife. Afastado, Tertuliano, no intervalo do processo em andamento, recebe memorando da fábrica com ordem de desocupação da casa no prazo de trinta dias. Por seu procurador - o advogado do sindicato, José Gomes da Silva o trabalhador ajuíza Ação de Consignação em pagamento dos aluguéis atrasados que a fábrica se recusava a receber.

Na primeira audiência, em 23 de setembro, é decidido que a fábrica proceda à readmissão do funcionário e receba a quantia referente aos cinco meses de aluguel. $\mathrm{A}$ Companhia Rio Tinto se ausenta da audiência e continua recusando o recebimento dos aluguéis atrasados. $O$ juiz determina fazê-lo à revelia da Companhia.

No prazo de contestação, a fábrica entra com recurso, para novo julgamento. Distinguem-se as testemunhas arroladas por Tertuliano: o serralheiro Antônio Fernandes de Andrade e o enfermeiro Manoel Pereira Ramos. Antônio Fernandes, à época, já se destaca, na oposição política à fábrica (ganha em 1960 a eleição para presidente do Sindicato Têxtil e em 1963 é eleito prefeito de Rio Tinto). Na petição inicial, seu defensor alega que o 
trabalhador sofria "uma pressão extraordinária por parte dos dirigentes da Companhia de Tecidos Rio Tinto"16, o que se confirma no depoimento de Manoel Pereira:

Que a Companhia Rio Tinto, ré nesta Ação, vem se recusando ultimamente a receber o referido aluguel por questões políticas, que a ré enviou ao autor um Memorando intimando este a desocupar o prédio no prazo de 30 dias, por falta de pagamento, que a ré, desde que o autor tomou rumo político diferente do réu, que vem pedindo a casa ${ }^{17}$.

À audiência, as partes interessadas não comparecem. Em sentença, o juiz Hermilo Ximenes julga procedente a ação do trabalhador, fixando a importância dos aluguéis em depósito judicial. A Companhia não contesta o mérito, que, em termos legais, não é mais possível, devido à ausência em duas audiências. Ao final do processo, em 19 de fevereiro de 1960, a fábrica, por intermédio de Pedro Monteiro de Lima - gerente do escritório de administração imobiliária -, recebe os aluguéis de maio de 1959 a janeiro de 1960.

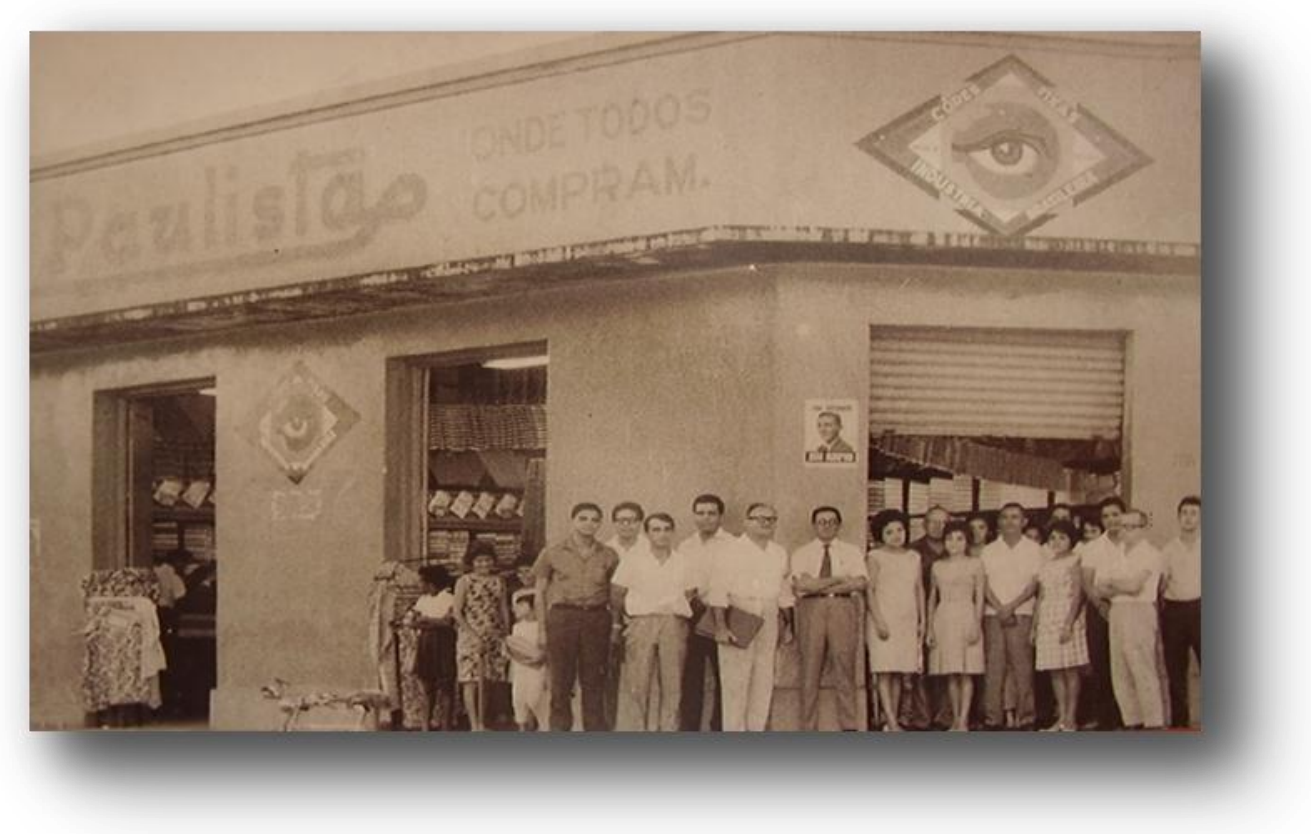

Figura 3 - Lojas Paulista em Rio Tinto, com funcionários e trabalhadores da Fábrica. Primeira metade da década de 1960. Arquivo: Antônio Luiz da Silva (Rio Tinto - PB).

Na mesma razão apresentada por Tertuliano, outra operária ajuíza uma ação: Maria Francisca Santos, tecelã desde 1953, é demitida em 1959. Na petição, seu advogado,

\footnotetext{
${ }^{16}$ Processo n. 130. Ação de Depósito. Autor: Tertuliano Dias de Lima. Ré: Companhia de Tecidos Rio Tinto. 8 de setembro de 1959. P. 3. Caixa - Ano de 1959. Arquivo do Fórum de Rio Tinto.

${ }^{17}$ Processo n. 130. P. 16.
} 
Adailton Coelho $\operatorname{Costa}^{18}$, aborda os motivos da rescisão do contrato de trabalho: "Que por motivo de não ter seguido a orientação política da fábrica, vem sendo perseguida, sendo este ainda o motivo capital de seu afastamento do trabalho"19. A fala do advogado denuncia a coação aos trabalhadores em razão de expressarem ideias contrárias aos interesses da fábrica, notadamente quando se verificam episódios de participação nas lutas sindicais.

Com a demissão, a fábrica ordena de imediato a desocupação da casa. Pela petição, é evidente a represália contra Maria Francisca, com a retenção da indenização, somente efetuada após desocupação do imóvel. Em contundente registro, com tom de denúncia, Adailton C. Costa informa que o patrimônio imobiliário dos Lundgren faz de Rio Tinto uma cidade 'tipo 'sui generis', em que toda a população habita em dependência da fábrica, ou seja, em casa pertencente à indústria"20.

Mesmo em vãs tentativas, a tecelã procura a direção da tecelagem para pagamento dos aluguéis, entretanto, os responsáveis pela gerência das casas são orientados a não receber nenhuma quantia. À audiência de 20 de novembro, Maria Francisca e a Companhia de Tecidos Rio Tinto não comparecem, e se concluem os autos em caso de ausência das partes envolvidas. O juiz estipula o prazo de 60 dias para ré e autora requererem nova assentada, o que não é feito, resultando na conclusão dos autos em 27 de fevereiro de 1960 (arquivados em 1971, após tentativa, em 1966, de reabertura). A ausência da tecelã é registrada; o oficial de justiça diz haver deixado de intimá-la, pois a operária não residia mais na cidade e haveria desistido da ação. A demissão da operária, apesar de contestada, não constitui o motivo da ação; em pauta estava a permanência na casa da vila operária, seu direito à moradia.

\footnotetext{
${ }^{18}$ Este advogado, ao lado de Sebastião Lins e José Gomes da Silva, integra a estrutura do Sindicato Têxtil de Rio Tinto, oferecendo suporte jurídico aos operários.

${ }^{19}$ Processo n. 141. Consignação e Pagamento. Autora: Maria Francisca Santos. Ré: Companhia de Tecidos Rio Tinto. 22 de setembro de 1959. P. 2. Caixa - Ano de 1959. Arquivo do Fórum de Rio Tinto.

${ }^{20}$ Processo n. 141. P. 2. Hoje em dia, os Lundgren ainda são proprietários de grande parte do patrimônio imobiliário da cidade, desde as casas da vila operária, prédios da fábrica, cinema, igreja, até algumas propriedades de terras em torno de Rio Tinto. O exemplo da igreja é emblemático: ainda hoje seu prédio pertence à fábrica e não à Arquidiocese da Paraíba.
} 
As ações de despejo promovidas pela fábrica contra operários sem estabilidade agravam o problema de moradia, pois, se "nos tempos do coronel Frederico ${ }^{21}$ a habitação consistia em um fator de atração ao operariado, passa a constituir um entrave aos novos interesses do capital ${ }^{\prime 22}$.

Alguns trabalhadores demitidos e ameaçados de despejo tentavam negociar com o gerente imobiliário - Pedro Monteiro - a permanência na vila. Entretanto, as respostas do responsável eram ríspidas. Exemplo disso foi sua reação ao dramático apelo de 'eu não tenho onde morar' do trabalhador Nilson F. de Lira: "Vá morar debaixo de uma ponte!", obtempera incisivamente Monteiro. Em outubro de 1961 (trabalhava desde 1938 - em períodos alternados - e com contrato efetivado em 1956) a fábrica rescinde seu contrato, com indenização de vinte mil cruzeiros (CR\$ 20.000,00) estabelecendo, de modo arbitrário, uma condição verificada em casos similares: pagamento de indenização condicionado à desocupação da moradia. Tal fato é questionado pelo advogado, evidenciando a força do poder econômico e a ineficácia no cumprimento da lei, como "um jato de lama na face da Justiça":

Como se observa, doutor julgador, o poderio econômico vem "impondo" tais acordos; tais modalidades de acordo frontalmente contra a lei. Porquanto uma diferente modalidade de DESPEJAR inquilinos que, de maneira alguma poderiam ser forçados a tal situação vexatória. Esta qualidade de despejo, que força os operários pela necessidade, pelo desemprego, pela fome; pelo não pagamento de quantias previamente certas - constitui-se num verdadeiro atentado às nossas leis: é como que um jato de lama na face da Justiça ${ }^{23}$.

A situação de desemprego e descumprimento das leis trabalhistas por parte da tecelagem torna mais precária a condição de Nilson, com sete filhos, na iminência de perder a moradia. Nesse momento, a cidade de Rio Tinto - emancipada em 1956 - continua sob o controle dos Lundgren, haja vista que para residência é preciso autorização da fábrica. Adverte o advogado que a "cidade não é livre, cidade que não é como as outras cidades, que pertencem a todos os cidadãos"24.

\footnotetext{
${ }^{21}$ Expressão utilizada por José Sérgio Leite Lopes para se referir a época em que Frederico Lundgren dirigia as tecelagens de Paulista e Rio Tinto. Segundo os operários representava um período em que não faltava emprego. Isto até 1946, data de seu falecimento.

${ }^{22}$ MACÊDO, Maria Bernadete. Op. cit., p. 190.

${ }^{23}$ Processo n. 551. Ação de Consignação em Pagamento. Requerente: Nilson Francisco de Lira. Requerida: Companhia de Tecidos Rio Tinto. 16 de agosto de 1962. P. 2. Caixa - Ano de 1962. Arquivo do Fórum de Rio Tinto.

${ }^{24}$ Processo n. 551. P. 3.
} 
A ação ajuizada acarreta a ordem de desocupação de sua moradia no prazo de 90 dias. Em petição, o advogado do trabalhador contesta as razões da fábrica, apresentando como argumento a constante demolição de casas na vila operária, o que fortalecia a reivindicação de permanência na moradia:

A autora não tem necessidade de prédios, de humildes prédios como aqueles (todos) da Rua Barão do Triunfo. Porque bastantes provas poderão apresentar-se no decurso da presente, de como a autora tem destruído boas casas de moradia nas ruas de sua cidade ${ }^{25}$.

A Companhia mais uma vez é derrotada. O despejo não é determinado pelo juiz, e a derrota jurídica implica receber os aluguéis atrasados, o que motiva o direito de permanência do operário na casa.

Outros processos, com sentença favorável aos trabalhadores, são movidos por Floriano Rodrigues de Araújo, Luíza de Freitas Araújo e José Gomes Marçal.

Trabalhador desde 1953, Floriano Rodrigues de Araújo tem o contrato rescindido em 20 de fevereiro de 1962, portanto com menos de 10 anos de serviço. A Companhia de Tecidos, mais uma vez, dispensa o trabalhador, para impedir sua estabilidade. Despedido, tem a indenização retida, e do valor de CR\$ 73.920,00 (setenta e três mil, novecentos e vinte cruzeiros) a fábrica libera somente CR\$ 43.920,00 (quarenta e três mil, novecentos e vinte cruzeiros).

Como em outros casos, a quantia restante apenas seria paga após a desocupação da moradia. Segundo o advogado José Gomes da Silva, ao reter CR\$30.000,00 (trinta mil cruzeiros), a Companhia faz apropriação indébita ${ }^{26}$. À audiência, a Companhia e seu representante legal não comparecem, o que levou o julgamento da ação a ser favorável ao trabalhador. Outras ações idênticas são ajuizadas pela operária Luiza Freitas Araújo ${ }^{27}$ e José Gomes Marçal ${ }^{28}$.

\footnotetext{
${ }^{25}$ Processo n. 555. Ação de Despejo. Requerente: Companhia de Tecidos Rio Tinto. Requerida: Nilson Francisco de Lira. 20 de agosto de 1962. P. 3. Caixa - Ano de 1962. Arquivo do Fórum de Rio Tinto.

${ }^{26}$ Processo n. 500. Ação de Consignação em Pagamento. Requerente: Floriano Rodrigues de Araújo. Requerida: Companhia de Tecidos Rio Tinto. 8 de maio de 1962. P. 2. Caixa - Ano de 1962. Arquivo do Fórum de Rio Tinto.

${ }^{27}$ Processo n. 650. Ação de Consignação em Pagamento. Requerente: Luíza de Freitas Araújo. Requerida: Companhia de Tecidos Rio Tinto. 27 de abril de 1963. Caixa - Ano de 1963. Arquivo do Fórum de Rio Tinto.

${ }^{28}$ Processo n. 758. Ação de Consignação. Requerente: José Gomes Marçal. Requerida: Companhia de Tecidos Rio Tinto. 3 de dezembro de 1963. Caixa - Ano de 1963. Arquivo do Fórum de Rio Tinto.
} 
Este trabalhador, após nove anos na função de tecelão, é demitido em outubro de 1963, depois de a fábrica recusar-se a receber o pagamento do aluguel, com notificação de desocupação em um mês.

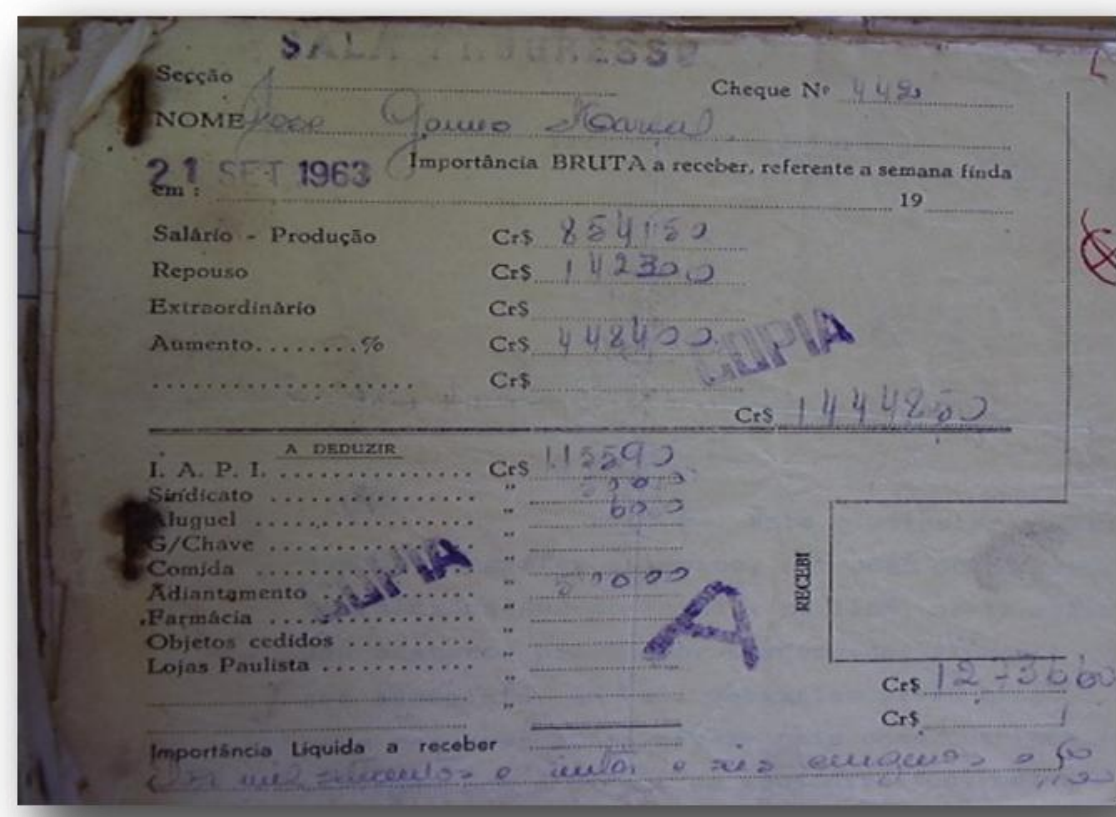

Figura 4 - Descrição dos descontos salariais: I.A.P.I.: sindicato, aluguel, comida, adiantamento, farmácia e Lojas Paulista. Arquivo Fórum de Rio Tinto (PB) - Acervo documental do autor.

Na audiência de 29 de setembro de 1964, pelo não comparecimento da fábrica ou de seu procurador, é determinado pelo juiz ${ }^{29}$ o depósito da quantia dos aluguéis atrasados. Como se vê, à demissão e desemprego soma-se o processo de despejo da vila operária.

A fábrica alega razões de propriedade e determina a ocupação exclusiva da moradia aos que têm vínculo empregatício. Este argumento está presente nas ações de manutenção de posse e de despejo, a exemplo do caso das operárias Izaura Vieira Guimarães e Maria

\footnotetext{
${ }^{29}$ Notar que nesse período o juiz da Comarca de Mamanguape, Rivando Bezerra Cavalcanti, responde pela Comarca de Rio Tinto, haja vista que com o golpe civil-militar de 1964, o juiz Hermilo Ximenes havia deixado suas atividades.
} 
Joselita G. de Barros: "A casa ocupada pelo notificado faz parte do núcleo residencial que a empregadora notificante construiu para moradia exclusiva dos seus empregados" ${ }^{\prime 30}$. As operárias têm os contratos rescindidos em março e junho de 1961, respectivamente. 0 processo de Maria Joselita se estende até 1971, tempo em que a Companhia de Tecidos desiste da ação em decorrência de a operária haver desocupado o imóvel.

No processo contra Izaura Vieira, os argumentos da fábrica são desmontados. Em notificação judicial, de 21 de março de 1962, a fábrica ordena a desocupação do imóvel no prazo de 90 (noventa) dias. Pelo não cumprimento da notificação, que ultrapassa os 120 (cento e vinte) dias, a Companhia requer despejo imediato. Nesses casos, apesar de notificados, os operários se recusam a entregar a casa, e os processos podem se arrastar por anos a fio.

Izaura Vieira contesta a ação, e na audiência de 7 de março de 1964 são arroladas três testemunhas. A primeira, Alcides Pereira da Silva, funcionário público federal, apresenta razões contrárias ao despejo, contraditando a fábrica. Para ele, em Rio Tinto residem pessoas das mais diversas profissões e que necessariamente não têm vínculos com a tecelagem. Ele mesmo, funcionário público federal, mora em casa que não se distingue das outras e das dos operários da fábrica. E conclui seu contundente depoimento em favor de Izaura, reiterando "que várias pessoas já foram operárias da fábrica, mas que hoje continuam a morar em casas a ela pertencentes, e que as melhores casas da cidade são justamente habitadas por pessoas que não têm vínculo econômico com a C.T.R.T." ${ }^{\prime 31}$

O depoimento ressalta o respeito à norma legal e ao direito dos inquilinos, contraditando os proprietários da fábrica. Outra testemunha, João Justino da Silva, afirma categoricamente "que nas mesmas ruas e em casas ocupadas por operários da Fábrica Rio Tinto moram também pessoas das mais diversas profissões e que não estão a ela vinculadas." Ele próprio é agricultor, e mora na vila operária, em casa igual às dos trabalhadores da tecelagem. A última testemunha, Juraci Guedes Alcoforado, ressalta sua condição de funcionário federal, que não era ligado à Companhia de Tecidos e morava em

\footnotetext{
${ }^{30}$ Processo n. 521. Ação de Despejo. Requerente: Companhia de Tecidos Rio Tinto. Requerida: Maria Joselita G. de Barros. 15 de junho de 1962. Caixa - Ano de 1962. P. 2. Arquivo do Fórum de Rio Tinto.

30. Processo n. 553. Ação de Despejo. Requerente: Companhia de Tecidos Rio Tinto. Requerida: Izaura Vieira Guimarães. 20 de agosto de 1962. Caixa - Ano de 1962. P. 20 e 21. Arquivo do Fórum de Rio Tinto.

${ }^{31}$ Processo n. 553. P. 24-25.
} 
casa similar às dos operários. Assinala, ainda, a iniciativa da fábrica de demolir várias casas desabitadas na cidade.

Isto só ratifica que as falas das testemunhas funcionam decisivamente para contraditar a afirmação dos Lundgren de que necessitavam das moradias dos operários demitidos, visando à ocupação por outro trabalhador que não possuía casa. O posicionamento das testemunhas nos leva a observar a articulada organização dos depoimentos nos processos, demonstrando a solidariedade nos testemunhos em favor dos companheiros de labuta. O procurador da operária, Sebastião Lins, esclarece que tanto neste como em outros casos, a fábrica não apresenta testemunhas a seu favor, e reitera que a operária, com seus serviços, foi parte integrante no desenvolvimento da fábrica Rio Tinto:

\begin{abstract}
Não é de se despejar uma pobre velha que já deu tudo que tinha de melhor na sua mocidade, trabalhando para o enriquecimento da autora, esta imensa riqueza em progresso. Cabia à autora o ônus da prova, o que não procurou fazer, nem sequer arrolando testemunhas, confiando que a Justiça Ihe dará ganho de causa pelas suas meras afirmações ${ }^{32}$.
\end{abstract}

O processo permanece parado até 18 de maio de 1971, data em que a fábrica desiste da ação, pois o imóvel retorna à posse definitiva. Mais uma vez as pressões exercidas pela fábrica ao longo do processo fazem com que a operária saia derrotada nesta contenda. Outro caso é do operário José Alves ${ }^{33}$, que desobedece à notificação da fábrica e protela a ação por mais de oito meses. Passado o período de pressão, a Companhia informa ao juiz a desistência da ação.

O número de desempregados nesta conjuntura se amplia. Assim, diante do problema, os operários aumentam os embates com a fábrica, para, pelo menos, garantirem morada na vila operária: alguns por via jurídica, outros pela ocupação de casas destinadas à demolição. Nesse sentido, ocupações são registradas, enquanto a tecelagem seguia demolindo casas - como se vê nos autos dos processos - desocupadas e em bom estado de conservação. Para a fábrica, "as invasões não param, deixando bem evidente de que existe

\footnotetext{
32 Processo n. 139. Ação Privada de Despejo. Autora: Companhia de Tecidos Rio Tinto. Réu: José Alves de Souza. 21 de setembro de 1959. Caixa - Ano de 1959. Arquivo do Fórum de Rio Tinto.

${ }^{33}$ Processo n. 717. Ação Pública. Réu: Lademir Gomes de Melo. Vítima: Companhia de Tecidos Rio Tinto. 9 de outubro de 1963. Caixa - Ano de 1963. P. 2. Arquivo do Fórum de Rio Tinto.
} 
planos pré-determinados para evidenciarem um prestígio subversivo a ordem e ao direito que garantem a propriedade privada ${ }^{\prime 34}$.

É nessas circunstâncias que, em outubro de 1962, casas na Avenida Rio Branco, na Rua Regina e na Rua Santos Dumont, na Vila Regina (outra seção e vila da fábrica, distante 2 km do centro da cidade), são ocupadas por operários. O fato suscita, meses depois, ação de manutenção de posse da Companhia, declarando esta que "a forma de ação dos réus, é de maneira que fere a Lei, desrespeitando a ordem pública, sendo indivíduos sem profissão ou ocupações certas, querem forçar a sua permanência nesta cidade ${ }^{\prime 35}$.

Mesmo assegurando não terem os operários profissão, em audiência de outubro de 1963 percebem-se certas incoerências nas declarações da Companhia. Os envolvidos na querela são identificados e citados para comparecer em audiência. Francisco Bernardo de Araújo, por exemplo, é casado com operária da fábrica, e apresenta provas para tanto: "sempre pagou aluguel a Companhia de Tecidos Rio Tinto; tem recibos do pagamento de luz da dita casa e a prova dos pagamentos do aluguel se encontra registrado em um livro da Companhia empregadora ${ }^{\prime 36}$. Complementa expondo que tramita uma ação movida por ele, pois a Companhia se recusa a receber os aluguéis.

Já o agricultor Antônio Pedro declara que, como tem uma filha na fábrica, firmou contrato de aluguel "pago pela sua filha e descontado quinzenalmente do seu cheque." Idêntica é a situação de Maria Marinho da Silva, operária da fábrica que paga aluguel, sendo este descontado quinzenalmente em seu cheque, como previamente acordado com o gerente das casas, Pedro Monteiro. Em janeiro de 1964, o advogado dos trabalhadores ingressa com pedido de liminar, solicitando revista dos autos, pois, segundo sua interpretação:

Dentre os RR muitos são operários da autora, ou tem família trabalhando na indústria da suplicante. Outros ainda estavam trabalhando como obreiros dela e foram indenizados sem que para tanto houvesse causa. E há quem tenha requerido Ação de Consignação de Pagamento dos alugueres do prédio pedido ${ }^{37}$.

\footnotetext{
${ }^{34}$ Processo n. 632. Ação de Manutenção de Posse. Proponente: Companhia de Tecidos Rio Tinto. Proposto: (?). 22 de março de 1963. Caixa - Ano de 1963. P. 3. Arquivo do Fórum de Rio Tinto.

${ }^{35}$ Processo n. 632, p. 13.

${ }^{36}$ Processo n. 632, p. 15.

37 Júlio Justino da Silva, 78 anos. Serralheiro, começou a trabalhar em 1948 na fábrica. Entrevista realizada em Rio Tinto, julho de 2005.
} 
Nesses processos, os trabalhadores são por várias vezes bem-sucedidos nas reclamações. Nessas vitórias, sobressai o juiz Hermilo Ximenes, que, à frente da Comarca de Rio Tinto, é personagem de destaque. Os operários veem-no com bons olhos: "todo mundo gostava, não era brincadeira não, o cara falava com você assim no meio da rua, todo uniformizado." 37

O magistrado, assim, atuava em defesa dos direitos dos trabalhadores do campo (via Liga Camponesa de Rio Tinto e Mamanguape) e da cidade (fábrica de tecidos Rio Tinto). Essas duas forças "procuraram atuar juntas, principalmente no campo das reivindicações trabalhistas, apoiadas pelo Juiz, que Ihes dava cobertura 'fazendo a lei valer'”' ${ }^{38}$. Tanto em texto historiográfico, como na memória dos trabalhadores, a oposição do juiz ao poderio da fábrica é confirmada. Contudo, é relevante verificar que Hermilo Ximenes é posto na Comarca de Rio Tinto por interferência dos Lundgren, como ele mesmo informa:

Eu fui para Rio Tinto indicado, levado por pessoas de minha família pelo pai de um cunhado meu, que era fiscal coletor federal na cidade de Rio Tinto. Amigo dos Lundgren, ele pediu o lugar para mim e eu fui nomeado, fui transferido pelo governador Pedro Gondim ${ }^{39}$.

Conquanto levado para a cidade pelos mandatários da tecelagem, e inicialmente mantendo-se próximo de um dos diretores da fábrica - o alemão Otto Hoffman -, Hermilo Ximenes logo se distancia da fábrica, tornando-se um dos seus opositores. "Tinha interesse pessoal de cortar o poder da companhia", assevera José Antônio da Silva, que informa o momento em que se torna personagem de oposição:

Foi a companhia que trouxe ele para aqui, ele andou muitas vezes com seu Hoffman, mas ele inteligente, virou as costas para companhia e ficou do lado do trabalhador. Aí o trabalhador baseado que ele era amigo do sindicato, começou ir para a casa dele ${ }^{40}$.

Ao assumir a Comarca ${ }^{41}$, o juiz logo toma conhecimento das práticas de suborno dos Lundgren, procedimento usual em suas estratégias de controle de esferas de poder. Assim rememora o momento em que o escrivão o informa de tais métodos: "Olhe, Doutor, antes

\footnotetext{
${ }^{38}$ AUED, Bernadete Wrublevski. A Vitória dos Vencidos (Partido Comunista Brasileiro - PCB - e Ligas Camponesas 1955-64). Campina Grande: Departamento de Sociologia - UFPB (Mestrado), 1981, p. 48.

${ }^{39}$ Hermilo de Carvalho Ximenes. Juiz de Rio Tinto no período de 1959 a 1964. Entrevista realizada em João Pessoa, julho de 2005.

40 José Antônio da Silva , 78 anos. Entrou para a fábrica em 1940, trabalhou como carpinteiro e, no pós-1964, tomou parte na diretoria do sindicato. Em 1967 se tornou presidente, posteriormente vice-prefeito e vereador em Rio Tinto. Entrevista realizada em Rio Tinto, novembro de 2006.

${ }^{41}$ Primeiro Juiz de Rio Tinto. A União, 4 de fevereiro de 1959.
} 
do Sr. chegar aqui, era comum se mandar todo mês um envelope do Juiz, o envelope do Promotor e o envelope do Delegado de Mamanguape, e quem preparava esse envelope com o dinheiro todo mês para mandar era eu ${ }^{\prime \prime 42}$. A Hermilo Ximenes, a direção da fábrica oferece uma casa para sua moradia, entre as melhores na cidade. Já ciente dos métodos de suborno e aliciação, comunica à direção sua pretensão do pagamento de aluguel, como outros moradores da cidade, recusando peremptoriamente a oferta:

Fui procurado para não pagar o aluguel da casa onde eu morava, na praça central da cidade, uma casa relativamente de nível alto. Aqueles chalés, entendeu? Mas eu não aceitei, e como eles demorassem em mandar o recibo, eu disse a um funcionário da fábrica de categoria que, se o Sr. Otto Hoffmann - que era um dos diretores - não mandasse o recibo cobrando o meu aluguel, eu depositaria o valor do aluguel que eu arbitrasse em Cartório.

Em suas memórias, Ximenes constrói uma autoimagem de feitio popular (deixa transparecer um depoimento pronto, e evoca traços da memória organizada, afirmando-se como personagem de referência entre os operários), de proximidade com as demandas dos trabalhadores, revelando certo traço paternalista nas relações:

Olhe, eu fazia no expediente da manhã a chamada justiça de paz, logo, ás 07h00min da manhã. Ás 06h30min já havia gente sentada nos bancos da praça esperando entrar na minha casa para falar comigo, eu só começava a receber o povo às 08:00hs tinha sempre um soldado a minha disposição e o soldado ia mandando as pessoas entrarem para falarem comigo de acordo com a ordem de chegada. E eu até 11 h00min ficava nesse trabalho ${ }^{43}$.

A memória operária sobre a atuação do juiz reforça sua imagem de liderança e seu trabalho em favor dos trabalhadores: "Ximenes era um líder, uma parte dos operários gostava dele, a maioria dos operários, ele como juiz incentivava o povo, e o povo achava que tava bem, que tava certo, né? Ele gostava dos operários, ele era sempre a favor dos operários, ele não era contra" ${ }^{44}$. Sua condição de destaque, em Rio Tinto, põe-no ao lado de Antonio Fernandes e José Gomes da Silva, destacados oponentes dos Lundgren ${ }^{45}$.

\footnotetext{
${ }^{42}$ Hermilo de Carvalho Ximenes. Op. cit.

${ }^{43}$ Hermilo de Carvalho Ximenes. Op. cit.

${ }^{44}$ Severino Nascimento Soares - 72 anos. Trabalhou como tecelão de 1949 a 1960, quando passou a trabalhar como vigia. Entrevista realizada em Rio Tinto, julho de 2005.

${ }^{45}$ Perguntado sobre ligações com a política, especificamente com os comunistas, foi enfático: Nunca fui comunista! Entretanto, Luiz Hugo Guimarães - ex-sindicalista dos bancários da capital - relata que Ximenes, ainda quando cursava Direito em Recife, militou na Juventude do Partido Comunista de Pernambuco. MELLO, José Octávio de A. Sociedade e Poder Político no Nordeste - O caso da Paraíba (1945-1964). João Pessoa: Universitária, 2001, p. 275.
} 
Ao concluirmos, compreendemos que os processos analisados demonstram as formas como empregadores e empregados, diante da Consolidação das Leis do Trabalho CLT, travam luta jurídica de redefinição de relações, no período entre 1959 e 1964, quando as ações se avolumaram. Não obstante, as dificuldades de deslocamento para as várias audiências na Junta de Conciliação na capital e a pressão exercida pela fábrica para que se desocupassem a casa em prazos estipulados e tivessem o contrato de trabalho rescindido, logo são sentidas. Tais ações nesta conjuntura ratificam que os trabalhadores estavam cientes de que uma via para lutar pela permanência no trabalho, e por extensão pelo direito de moradia, é o cumprimento da lei. Nesta esteira, é importante a influência seminal do historiador E. P. Thompson e o diálogo entre a História Social e o Direito, em seu estudo sobre a origem da Lei Negra na Inglaterra do século XVIII. Guardadas as devidas especificidades e particularidades, ao entrarmos em contato com o trato que este historiador dispensa ao Direito, neste trabalho levamos em conta as necessárias mediações de leitura, tanto em relação à teoria, como no tratamento metodológico das fontes ${ }^{46}$. Nestas disputas jurídicas, os trabalhadores de Rio Tinto souberam decisivamente utilizar-se da Lei e do Direito na luta contra os patrões. E muitos alcançaram os êxitos pretendidos.

Recebido em20/12/2009

Aprovado para publicação em24/02/2010

\footnotetext{
${ }^{46}$ THOMPSON, E. P. Senhores e Caçadores. Rio de Janeiro: Paz e Terra, 1987.
} 